\title{
HEPATIC CIRCULATION AND HEPATIC FUNCTION DURING ANAESTHESIA AND SURGERY III CHLOROFORM-INDUCED LIVER INJURY
}

\author{
A Galindo, M $\mathbb{D}, L$ D Maclean, $M$, \\ $\mathbb{R} \mathbb{B} \mathbb{G}$ GLBERT, M B , CH B, F F A R S , F R P (C), AND \\ $G$ Fred BRINDLE, M D , F R C $\mathbb{P}(\mathrm{C})$
}

HePatic HaEmodynamics under surgery and anaes|hesia have been studied, ${ }^{1,2}$ but the significance of these changes in the development of post-surgical hepatic injury is unknown The present study attempts to colrelate the hepatotoxic effect of chlor oform with the observed hepatic circulatory elfects ${ }^{2}$

\section{METHOD}

Sixty-five dogs were used in these experments Hepatic haemodynamics and liver function were studied in the acute preparations Hepatic function and liver hystology were studied in chronic ones

\section{Acute}

Nineteen dogs were studied in this group Anaesthesia and surgical preparation have previously been described in detal ${ }^{1}$ Chlorofon $m$ anaesthesia was administered in 11 experments using a Fluotec vaporizer Depth of chloroform anaesthesia was standardized when the normal corneal rellex had disappeared and the mean systemic blood pressure was depressed 30 per cent of the control value This depth was maintained for 1 to 3 hours In 8 experiments, no anaesthesia was given, and hypotension was induced by bleeding In this unanaesthetized gioup a 30 per cent reduction in mean blood pressure was likewise maintanned for 1 to 3 hours In both, groups a bromsulphthalein retention test (BSP) was done before the experiment and during the last 45 minutes of observation ( $5 \mathrm{mg} / \mathrm{Kg}$ I $\mathrm{V}$ injection, 45 minutes test period) SGOT serum levels were determined at the same tume Hepatic artery and portal vein blood-flow, mean arterial blood pressure, and the $\mathrm{pH}, p \mathrm{O}_{2}$, and $\mathrm{pCO}_{2}$ of simultaneous arterial and portal vein blood samples were determined as previously described The effects of high $p \mathrm{CO}_{2}$ were compared in the two groups of ammals

\section{Chronic}

Forty-s1x dogs were studied in this group Anaesthesia and artificial respiration were induced as in the acute preparations $\mathbf{A}$ femoral catheter was placed in the left femoral artery for recording of pressure and for blood sampling These

- Department of Neurology and Neurosurgery, McGill University and the Montreal Neurological Institute and Hospital, and the Department of Surgery, the Royal Victoria Hospital 
experiments were divided into two main giroups The first group acted as controls, while chloroform anaesthesia was given to the second The total experimental time was 48 hours, with the first three hours constituting the experiment proper Blood gas analyses were performed with the Micro-Astrup instrument using the SA (Siggaard-Andersen) nomogram BSP retention tests were performed with a Beckman electrophotometer, $5 \mathrm{mg} / \mathrm{Kg}$ of BSF being administered intralvenously and a blood sample being withdrawn 45 minites later The first BSP test was performed before each expermment, a second test during the final 45 minutes of the three-hour expermmental period, and a final test just prior to sacrifice of the animal 48 hours later SGOT determinations were made simultaneously with the BSP retention test in several anımals AI $\rfloor$ anumals were sacrificed with an intravenous administration of $90 \mathrm{mg} / \mathrm{Kg}$ of sodium pentobarbital Samples of liver from two different lobules were fixed in 10 per cent formalin for histological study The pathological findings in the liver were graded 0 to 4 , indicating a range from no injury to severe hepatic injury

In certain experiments the dogs were placed in a cage after three hours of the experiment and a six- to ten-hour recovely period was started This consisted in maintaning the dogs under 100 per cent $\mathrm{O}_{2}$ for one or two hours immediately following the experiment and then in an oxygen tent at an $\mathrm{O}_{2}$ concentration of 40 per cent for six hours Other anmals had no post-experimental care durnng the recovery period

Six dogs were mantained under severe hypoxia, i e with an $\mathrm{O}_{2}$ arterial blood saturation of from 30 to 70 per cent This group had no recovery and was considered the control group for the chloroform anaesthesia expeiıments It also provided an indication of the effects of acute severe hypoxia on liver function and liver pathology

Chloroform anaesthesia was administeled to twenty dogs under three different conditions (a) with atmospheric air (six dogs), (b) with 100 per cent $\mathrm{O}_{2}$ at one atmosphere of pressure (four dogs), and (c) with 100 per cent $\mathrm{O}_{2}$ at two atmospheres of pressure (ten dogs) Twenty more dogs were studied using the same experimental preparation, but some died immediately after the experıment, and in some no histological study of the liver was carried out Chloroform was not administered to them The effect of hypercarbia was studied in five, haemorrhage was noted in $\mathrm{SIX}$, and straightforward control of the experimental preparation for a three-hour period was observed in nine

\section{RESULtS}

The results from the acute preparations are compared in Figure 1 and Table $\mathbb{I}$ Chloi oform anaesthesia depresses hepatic blood-flow and portal $\mathrm{pO}_{2}$ These changes are greater than the modifications observed during a similar systemic blood-pressure reduction obtaned by blood loss The portal $p \mathrm{CO}_{2}$ under these crrcumstances is higher in the group administered chloroform than in the control group The effect of high arterial $p \mathrm{CO}_{2}$ on the hepatic artery blood-flow is opposite in the two groups Hepatic artery flow increases in the animals which did not have chloroform, while in the chloroform experiments the flow is further reduced 
PER CENT OF NORMAL

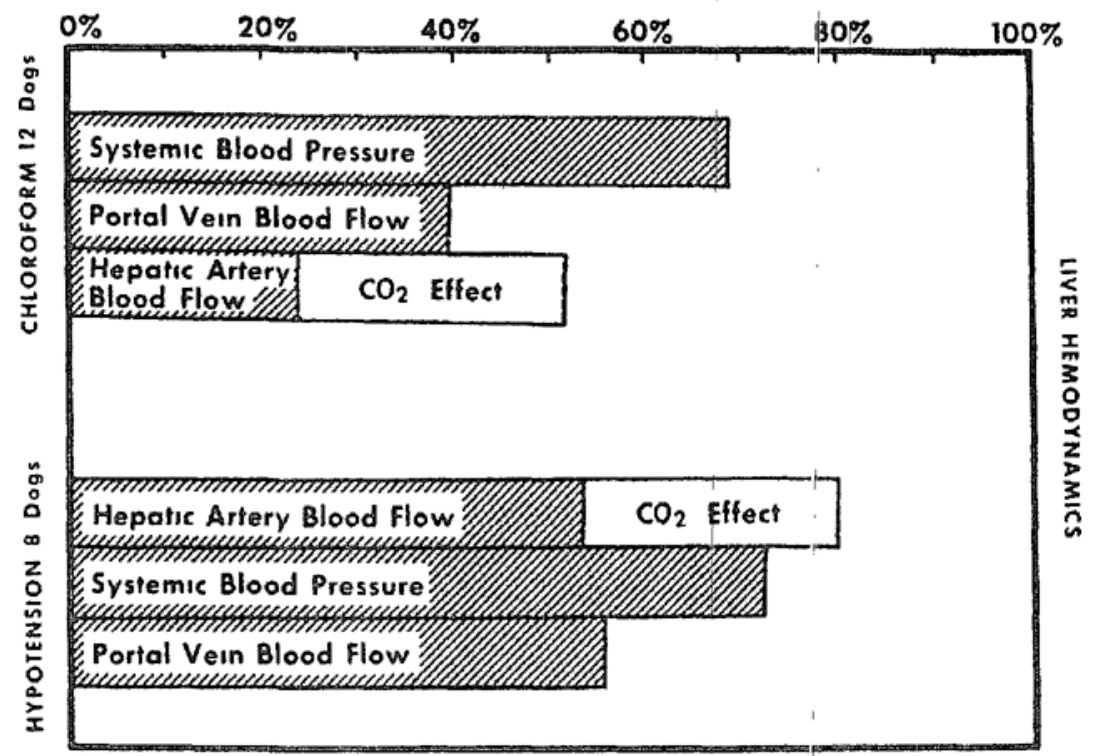

Figure 1 Carbon dioxide increased hepatic artery blood-flow in control experiments while it reduced it under chloroform anaesthesia

TABLE I

Comparison between Chiloroform and Haemorrhagic Arterial Blood-Pressure Reductions, and Their Effect on Portal Blood-Flow and Arterial to Portal $p \mathrm{O}_{2}, p \mathrm{CO}_{2}$ GRADIENTS

\begin{tabular}{|c|c|c|c|c|c|c|c|c|}
\hline \multicolumn{5}{|c|}{ Control } & \multicolumn{4}{|c|}{ Chloroform } \\
\hline Experiment & PB F & $\mathrm{PpO}_{2}$ & $\triangle p \mathrm{CO}_{2}$ & $\mathrm{BP}$ & $P B F$ & $\mathrm{PpO}_{2}$ & $\Delta p \mathrm{CO}_{2}$ & B P \\
\hline $\begin{array}{l}58 \\
59 \\
60 \\
64 \\
65 \\
66\end{array}$ & $\begin{array}{l}500 \\
550 \\
400 \\
450 \\
500 \\
800\end{array}$ & $\begin{array}{r}97 \\
73 \\
61 \\
596 \\
334 \\
172\end{array}$ & $\begin{array}{r}12 \\
4 \\
2 \\
5 \\
11 \\
12\end{array}$ & $\begin{array}{l}140 \\
165 \\
130 \\
130 \\
140 \\
170\end{array}$ & $\begin{array}{l}100 \\
200 \\
300 \\
100 \\
200 \\
400\end{array}$ & $\begin{array}{r}51 \\
48 \\
63 \\
78 \\
160 \\
68\end{array}$ & $\begin{array}{l}35 \\
17 \\
13 \\
15 \\
11 \\
38\end{array}$ & $\begin{array}{r}105 \\
100 \\
120 \\
100 \\
100 \\
80\end{array}$ \\
\hline \multicolumn{9}{|c|}{ 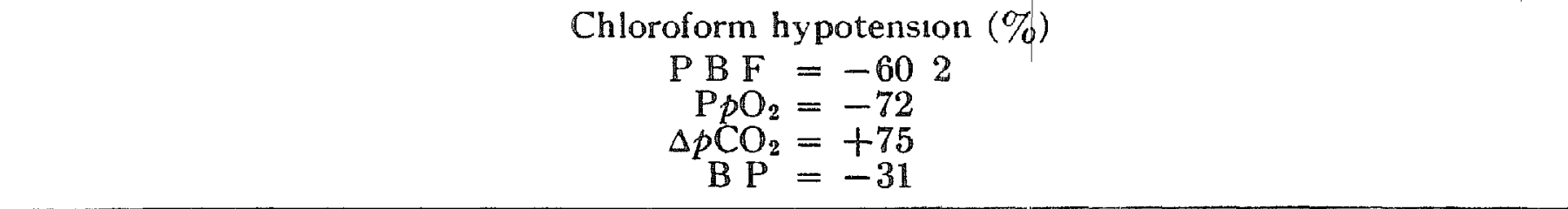 } \\
\hline \multicolumn{5}{|c|}{ Control } & \multicolumn{4}{|c|}{ Hypotension } \\
\hline Experiment & $\mathrm{PBF}$ & $\mathrm{PpO}_{2}$ & $\Delta p \mathrm{CO}_{2}$ & $\mathrm{BP}$ & $\mathbb{P B F}$ & $\mathrm{PpO}_{2}$ & $\Delta p \mathrm{CO}_{2}$ & B $P$ \\
\hline $\begin{array}{l}52 \\
54 \\
55 \\
49 \\
51 \\
5.3 \\
56 \\
57\end{array}$ & $\begin{array}{r}1300 \\
900 \\
60 \\
800 \\
400 \\
1300\end{array}$ & $\begin{array}{r}280 \\
90 \\
85 \\
184 \\
127 \\
80 \\
90 \\
76\end{array}$ & $\begin{array}{r}14 \\
16 \\
8 \\
7 \\
7 \\
14 \\
16 \\
5\end{array}$ & $\begin{array}{l}130 \\
130 \\
130 \\
140 \\
120 \\
130 \\
130 \\
115\end{array}$ & $\begin{array}{r}1000 \\
500 \\
200 \\
600 \\
100 \\
400\end{array}$ & $\begin{array}{r}160 \\
63 \\
67 \\
52 \\
64 \\
25 \\
54 \\
40\end{array}$ & $\begin{array}{r}6 \\
6 \\
9 \\
7 \\
10 \\
22 \\
12 \\
15\end{array}$ & $\begin{array}{r}95 \\
105 \\
75 \\
120 \\
95 \\
90 \\
90 \\
105\end{array}$ \\
\hline
\end{tabular}

Haemorrhagic hypotension $(\%)$

$$
\begin{aligned}
\mathrm{PBF} & =-44 \\
\mathrm{PpO}_{2} & =-44 \\
\triangle p \mathrm{CO}_{2} & =0 \\
\mathrm{~B} \mathrm{P} & =-28
\end{aligned}
$$

$\mathrm{PBF}=$ Portal vein blood-flow in flow units

$\mathrm{PpO}_{2}=$ Portal $p \mathrm{O}_{2}(\mathrm{~mm} \mathrm{Hg})$

$\Delta p \mathrm{CO}_{2}=\mathrm{A}_{1}$ terial-portal vein blood $p \mathrm{CO}_{2}$ difference in $\mathrm{mm} \mathrm{Hg}$

$B P=$ Mean arterial blood pi essure $(\mathrm{mm} \mathrm{Hg})$ 
TABLE; II

Correlations between liver Function Tests and Hepatic Circulation

\begin{tabular}{|c|c|c|c|c|c|c|c|c|c|c|}
\hline \multirow[b]{2}{*}{ HABF $(\%)$} & \multicolumn{2}{|c|}{ BSP $(\%)$} & \multirow[b]{2}{*}{$\mathrm{BP}(\%)$} & \multirow{2}{*}{$\begin{array}{c}\mathrm{HABF} \\
(\%)\end{array}$} & \multirow{2}{*}{$\begin{array}{c}\text { PVBF } \\
(\%)\end{array}$} & \multicolumn{2}{|c|}{$\operatorname{BSP}(\%)$} & \multicolumn{2}{|c|}{ SGOT } & \multirow[b]{2}{*}{$\mathrm{BP}(\%$} \\
\hline & C & $E$ & & & & $\mathrm{C}$ & $\mathrm{E}$ & C & $\mathrm{E}$ & \\
\hline \multicolumn{11}{|l|}{ Chloroform } \\
\hline $\begin{array}{l}+10 \\
-61 \\
-63 \\
-65 \\
-80\end{array}$ & $\begin{array}{ll}2 & 6 \\
9 & 2 \\
5 & 3 \\
5 & 6 \\
4 & 5\end{array}$ & $\begin{array}{ll}14 & 5 \\
31 & 5 \\
31 & 2 \\
17 & 5 \\
27 & 5\end{array}$ & $\begin{array}{l}-13 \\
-35 \\
-33 \\
-39 \\
-33\end{array}$ & $\begin{array}{l}-77 \\
-69 \\
-70 \\
-80 \\
-87\end{array}$ & $\begin{array}{r}-80 \\
-46 \\
-62 \\
-42 \\
0\end{array}$ & $\begin{array}{rl}10 & 0 \\
3 & 4 \\
9 & 5 \\
6 & 2 \\
6 & 0\end{array}$ & $\begin{array}{ll}17 & 0 \\
31 & 5 \\
23 & 0 \\
37 & 8 \\
10 & 6\end{array}$ & $\begin{array}{l}35 \\
38 \\
31 \\
43 \\
35\end{array}$ & $\begin{array}{l}70 \\
68 \\
43 \\
54 \\
61\end{array}$ & $\begin{array}{l}-25 \\
-40 \\
-44 \\
-61 \\
-30\end{array}$ \\
\hline
\end{tabular}

Control

\begin{tabular}{|c|c|c|}
\hline $\begin{array}{l}+43 \\
+33 \\
-10 \\
-15 \\
-16 \\
-37 \\
-50\end{array}$ & $\begin{array}{ll}2 & 5 \\
3 \\
3 \\
2 & 5 \\
4 \\
6 \\
7\end{array}$ & $\begin{array}{r}3 \\
7 \\
7 \\
4 \\
7 \\
75 \\
16 \\
12\end{array}$ \\
\hline
\end{tabular}

HABF $=$ Hepatic artery blood flow Per cent change from control

PVBF = Portal vein blood flow Per cent change from control

$\mathrm{BSP}=$ Bromsulphthalein retention test $\mathrm{C}=$ control $\mathrm{E}=$ experiment

SGOT = Serum levels of glutomic oxsalacetic transaminasse

$\mathrm{BP}=$ Mean arterial blood pressure per cent change from control

BSP showed a good correlation SGOT did not change significantly

TABLE III

Correlation between Liver Function Tests AND Liver Pathology 48 Hours after the

EXPERIMENT

\begin{tabular}{|c|c|c|}
\hline LP & $\operatorname{BSP}(\%)$ & SGOT \\
\hline 0 & 4 & 22 \\
\hline 0 & 55 & 21 \\
\hline 0 & 5 & 26 \\
\hline 0 & 5 & 80 \\
\hline 0 & 5 & 31 \\
\hline 05 & 14 & - \\
\hline 05 & 10 & 54 \\
\hline 05 & 175 & 58 \\
\hline 05 & 55 & 46 \\
\hline 1 & 36 & - \\
\hline 1 & 9 & - \\
\hline 2 & 375 & - \\
\hline 2 & 75 & - \\
\hline 25 & 487 & - \\
\hline 3 & 298 & - \\
\hline $\begin{array}{l}3 \\
3\end{array}$ & $\begin{array}{l}357 \\
275\end{array}$ & 二 \\
\hline 3 & 23 & 1600 \\
\hline
\end{tabular}

LP = Liver pathology 


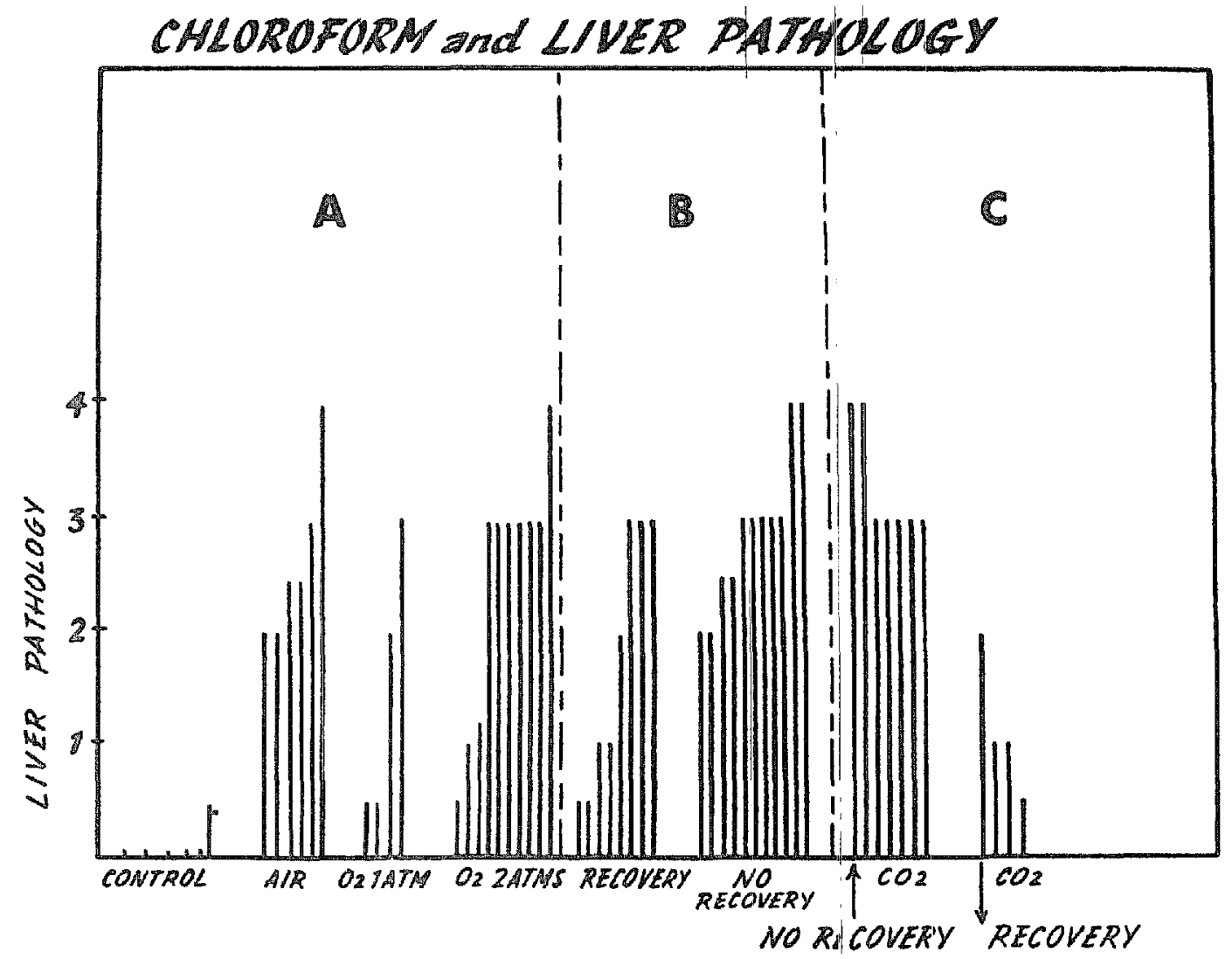

Figure 2 The incidence of hepatic damage after chloroform anaesthesia was related to systemic hypoxia and hypercarbia $\mathrm{A}$ There was no correlation between liver pathology and the administration of 100 per cent oxygen during the anaesthetic penod B There was some correlation when oxygen was administered during the immediate recovery period, and $\mathrm{C}$ there was a durect correlation between no recovery and hypercarbia and the incidence of hepatic injury

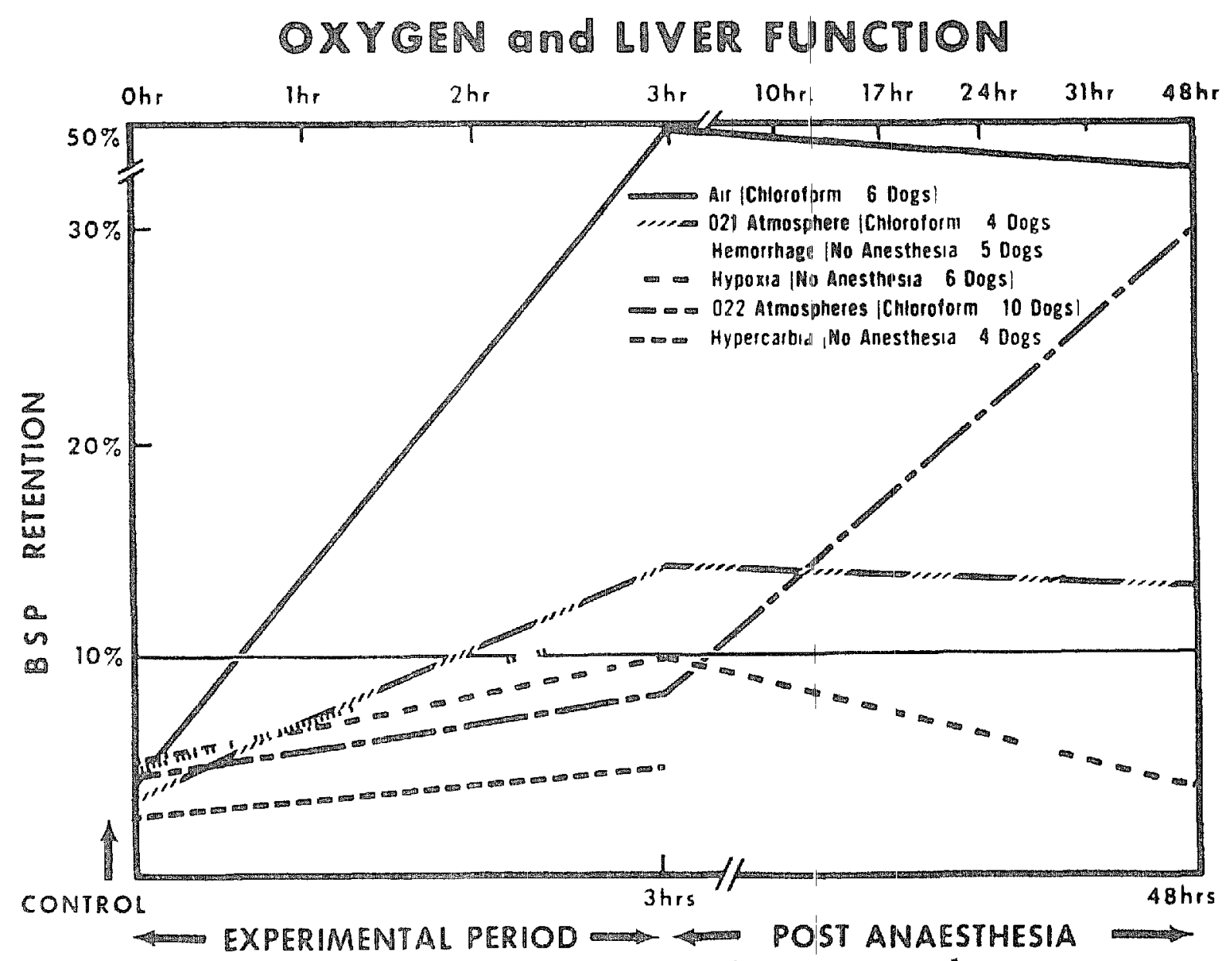

FigUre 3 BSP retention test was related to the trans-anaesthetic oxygenation The ummediate post-anaesthetic test had relative prognostic value for liver injury 
BSP and SGOT results in both groups of animals are consistent with the circulatory changes ( Table II)

The results of the experiments on the chronjc group are summarized in Figures 2 and 3 and Table III The liver function tests were consistent with the curculatory and pathological findings In the control animals acute hypoxia and hypercarbia ( 3 hours) had no pathological effect on the liver (Fig 3 ) However, all hypoxic animals under chloroform anaesthesia had abnormal livel-function tests When chloroform was given with 100 per cent $\mathrm{O}_{2}$ at two atmospheres of pressure, BSP and SGOT were normal at the end of a similar period Changes in hepatic blood-flow were similar in all chloroform experiments, and the only differences under hyperbaric oxygen were higher arterial and portal $p \mathrm{O}_{2}$ values

The final liver pathology was related to the oxygen administration during and after the period of anaesthesia as well as to the $p \mathrm{CO}_{2}$ values during the admmistration of the agent ( $F_{1}$ 2) Experiments in which the arterial $p \mathrm{CO}_{2}$ was normal or low and in which oxygen was administered during the anaesthetic as well as in the immediate recovery period, showed inild (2) to minimal hepatic injury (05)

\section{Discussion}

All dogs submitted to three hours of chloroform anaesthesia developed hepatic injury The severnty and extent of this injury was dependent upon the oxygenation and ventilation of the amimal Control experiments in which hypoxia and hypercarbia were maintained for a similar period of time showed no hepatic damage The effect of chloroform on the hepatic curculation persists after its administration $^{2}$ and might be related to the slow disappearance of chloroform from the liver ${ }^{3}$

Whether chloroform depresses the hepatic circulation and secondarily injures the hepatic cell, or whether the circulatory impaurment 1 s the result of an initual cellular damage is unknown In any event the administration of oxygen during and after chloroform anaesthesia reduces Hepatic injury to a minimum The pathological effect of high $\mathrm{CO}_{2}$ concentrations during chloroform anaesthesia, noted in man by others, ${ }^{4}$ seems to be related to a further reduction in hepatic oxygen supply High arterial $p \mathrm{CO}_{2}$ did not produce liver damage in control experiments and is even considered as a protection during respiratory insufficiency ${ }^{5} \mathrm{~A}$ biochemical effect of $\mathrm{CO}_{2}$ during chloroform anaesthesia cannot be ruled out

The liver function tests used (BSP and \$GOT) were correlated whth the patho$\log _{1}$ cal findings at the moment of sacrifice, It is suggested that a control determ1nation of these two tests before surgery followed by a second determination 48 hours after surgery, would indicate whether liver injury was present The seventy and prognosis of such a lesion could be determined with further studies

\section{General Conclusions}

There are several causes of reduced oxygen supply to the liver during a surgical operation Arterial hypotension, metabolic acidosis, trauma to the liver, and 
anaesthesia, alone or combined, all depress hepatic blood-flow and portal oxygen tension. Under some circumstances this depression extends into the post-surgical period when other factors, yet unknown, may be added to prolong hypoxia of the liver A normal liver can escape injury or is able to regenerate However, previous liver disease, sub-clinical viral hepatitis, or the high incidence of post-bloodtransfusion serum hepatitis ${ }^{6}$ may contribute, in a hypoxic liver, to the development of a severe injury Therefore, post-surgical hepatic necrosis must be regarded as a syndrome in which anaesthesia is one factor This could explain the difficulties reported in clinical studies which try to correlate anaesthesia with liver damage ${ }^{7-10}$ On the other hand, some anaesthetic agents such as chloroform contribute more than others to hepatic hypoxia, quite apart from their possible direct toxicity Since it is impossible to prevent some physiological disturbances during surgery, it seems safer not to use such an agent As for other anaesthetics, this study is being repeated with each one of them in drder to establish the crrcumstances in which they may contribute to post-surgical hepatic damage

Hyperbaric oxygen during surgery may be considered of therapeutic value in patients with marked liver dysfunction Finally, it seems clear that in the development of hepatic damage, the immediate recovery period is as important as the surgical intervention itself

\section{REFERENCES}

1 Galindo, A Hepatic Curculation and Hepatic Function during Anaesthesia and Surgery I Hepatic Haemodynamics Canad Anaesth Soc, J 12 262 (1965)

2 - - Hepatic Curculation and Hepatic Function during Anaesthesia and Surgery II. The Effect of Various Anaesthetic Agents Canad Anaesth Soc J 12337 (1965)

3 Hellenkant, G Distribution of Chloroform in Mice Actal pharmacol et toxicol 21 240 ( 1964 )

4 Sims, J L, Morris, L E, Orth, O S , \& Waters, R M The Influence of Oxygen and Carbon Dioxide Levels during Anesthesia upon Postsurgical Hepatic Damage J Lab \& Clin Med 38388 (1951)

5 ReFsum, H E Arterial Hypoxemia, Serum Activities o: SGOT and SGPT and LDH and Centrolobular Liver Cell Necrosis in Pulmonary Insufficiency Cln Sc 25369 (1963)

6 Hampers, C L, Prager, D, \& Senior, J R Posttransfusion Anicteric Hepatitis New England J Med 271747 (1964)

7 Mushis, W W, Rosen, M, Bowen, D J, \& Campberl, H Halothane and Liver Dysfunction A Retrospective Study Brit Med J 2329 (1964)

8 Lindenbaum, J \& Leifer, E Hepatic Necrosis Associated with Halothane Anesthesia New England J Med 268525 (1963)

9 Henderson, J C \& Gordon, R A The Incidence of Postoperative Jaundice with Special Reference to Halothane Canad Anaesth Soc J 11453 (1964)

10 Bunker, J P \& BLumenfeld, C M Liver Necrosis after Halothane Anesthesia Cause or Councidence New England J Med 268531 (1963) 